\title{
Simulation based learning versus clinical rounds in hospitals as a method of
}

\section{teaching in obstetrics}

\section{Ibrahim Mohamed Mohamed Daoud ${ }^{1}$, Awadia Gareeballah Suliman 2,3, Ahmed Abdelrahim} Mohammed $^{2}$, Maisa Mohammed Elzaki ${ }^{2,3}$, and Naglaa Elsir Mohammed ${ }^{1,4}$

1. Al Neelain University, Faculty of Medicine, Sudan

2. Department of Diagnostic Radiologic Technology, Faculty of Applied Medical Sciences, Taibah University,

Al-madinah Al-Munawarah, Kingdom of Saudi Arabia

3. Faculty of Radiological Sciences and Medical Imaging, Alzaiem Alazhari University, Khartoum, Sudan

4. Al-Ghad International College of Applied Medical Sciences, Kingdom of Saudi Arabia

\section{RESEARCH}

Please cite this paper as: Daoud IMM, Suliman AG, Mohammed AA, Elzaki MM, Mohammed NE. Simulation based learning versus clinical rounds in hospitals as a method of teaching in obstetrics. AMJ 2020;13(3):92-97. https://doi.org/10.35841/1836-1935.13.3.92-97

\section{Corresponding Author:}

Ibrahim Mohamed Mohamed Daoud

Al Neelain University, Faculty of Medicine, Sudan

Email: Ibrahimdaaoud@yahoo.com

\section{ABSTRACT}

\section{Background}

Increasing numbers of medical schools at Khartoum state with high numbers of medical students with limited teaching hospitals for training, associated with behavioural change of the patients towards accepting the training of medical student's makes simulation based education a best alternative to conventional clinical rounds with real patients.

\section{Aims}

To compare the educational effectiveness between simulations based learning and clinical rounds in hospitals as a method of teaching in obstetrics.

\section{Methods}

This was a descriptive cross sectional institutional-based study done in obstetric department at Faculty of medicine of Alneelain University 2017, to study simulation based learning as effective methods compare to clinical rounds in hospitals as a method of teaching. The data collected using pre-constructed, validated questionnaire inquiring about simulation based education and clinical rounds, questions designed to evaluate the perception of medical students and then tested the same students marks in their final MBBS obstetric exam comparing their results in questions based on pure clinical rounds versus questions based on pure simulation based learning, the sampling includes 129 students in final years in semester 11 , then the data analysed by statistical package for social sciences.

Results

In general more than halve 56.6 percent of the student preferred the clinical round than simulation based learning as method of teaching. Concerning contribution of tutor in the teaching and clearly defined of course objectives in obstetric the student stated that it was more effective and defined in simulation based learning than in clinical round 51.9 percent versus 41.1 percent and 45.7 percent versus 21.7 percent respectively. When assessing the exam results of both methods, the study verified that the student marks more in simulation based learning than clinical round so simulation based learning is better than clinical round as method of teaching as there is significant difference in means of exam remarks of those student (17.22 for simulation versus 11.12 for clinical round from total 20 marks), $P<0.01$.

\section{Conclusion}

The study concluded that simulation based education is substitute and filling the gap in teaching obstetric curriculum in undergraduate medical students.

\section{Key Words}

Simulation based learning, clinical rounds, medical student, teaching 


\section{What this study adds:}

\section{What is known about this subject?}

As far as the application of simulation based learning in our concern and to best of our knowledge: no published researches have been reported in the open literature found for Sudanese.

\section{What new information is offered in this study?}

Students had significantly better results in topic taught by simulation, so simulation based learning can fill the gabs and used as alternative to conventional clinical rounds as method of teaching.

\section{What are the implications for research, policy, or} practice?

This research will decreased the load on patients and hospitals by depending more on simulation teaching.

\section{Background}

There are many educational benefits of simulation in medical education includes: Deliberate practice with feedback, exposure to uncommon events and high-risk emergency cases, reproducibility, opportunity for assessment of learners and the absence of risks to patients. ${ }^{1}$

The principles of simulation-based education include feedback, curriculum integration, team training, transfer to practice, -skill acquisition and maintenance, mastery learning, simulation fidelity, outcome measurement. ${ }^{1}$

There are five different types of models that are used within the different simulation programs which are task trainers which includes air-way trainers, vascular access trainers, ultrasound trainers, lumbar puncture trainers, pelvic trainers and mechanical ventilation trainers, screen- based simulations incudes anatomy module, anaesthesia simulator and neonatal simulation, standardized-based simulation which provides interactive teaching through the innovative combination of technology and patient actors, tissue-based simulation is an opportunity to practice procedural skills outside of the clinical environment and the last type is virtual reality simulation using unique state-of-the-art virtual devices, it enables medical providers with high fidelity training procedural simulation enhanced with trueto-life tactile sensations. ${ }^{2,3}$

The World Health Organization (WHO) has provided standards for healthcare education to increase understanding professions and recommended the use of simulation for safe patient care in collaborative teams. On the other hand a lot of obstetrical emergencies are not suitable for students teaching due to it is high risks and time managements factors unlike in medicine and paediatrics departments which have a lot of chronic cases for education, besides these is social acceptance of female patients to male students in obstetrics vaginal examinations. Even normal labour simulator although not giving the real sense of life still it's a good practical tool in which students get the technique and the steps easily with high confidence: On the other hand, the tremendous advance in development in medical technology of simulators which makes this substitute just a matter of time. The only disadvantage for simulation is the high cost but as it can be used for many years with a high covering number of medical students, this should make it a cost effective substitute to conventional rounds of real patients. Simulation is an active teaching technique in healthcare education as it mimics a real-life event it provides unique opportunities for medical students to develop technical clinical skills, a holistic approach, improved communication skills, appropriate decision-making and improved critical thinking using appropriately designed scenarios. .There are many different types of simulation such as mannequin, partial task, standardized patients, hybrid, virtual and in-Situ simulations. $^{3}$

The objective of this study was to determine if simulation based education substitute conventional clinical rounds in undergraduate training in obstetrics and gynaecology.

\section{Method}

All students in final years in semester one of year 6 (semester 11) at Faculty of medicine of Alneelain University included in this study. Data were collected using preconstructed, confidential, validated, self-administered questionnaire inquiring about simulation based study and clinical rounds questionnaire designed to evaluate the view of staff medical students. The integral elements of queries were explained to them especially when the question is including parcel of terminologies of medical education. Also the student final remarks in obstetric examination was used (both type clinical round question marks and simulation based learning marks) to identify really which was good marks simulation based learning or clinical round in hospital, 129 students fill the questionnaire, any questionnaire that does not contain most of important information for research topic excluded (not answering most of important question). Several categories of variables was collected in the survey, of which those specifically designed to describe the respondents and the setting in which they worked. The questionnaire contain 
demographics data included age and some of important questions which clarify which one was preferred as method of teaching simulation based learning or clinical round in hospital. Then student remarks for final years obstetric exam clinical round final marks (patient history) and simulation based learning exam (speculum) should be evaluated to assess which was better degree. The study approved by committee of Alneelain University, Faculty of Medicine, all participants was informed about the purposes and objectives of the study and verbal consent was obtained from all participants. The data analysis by SPSS version 16 including frequencies and percentage, then compare mean by independent sample t- test ( student ttest) to compare the difference of mean of student marks in simulation based learning versus clinical round in hospital.

\section{Results}

The sampling includes 129 participants (65 female and 64 male) in their final years of MSc in Medicine (Six years, semester 11), 97.7 percent of them in age group 20-25 years with mean age 22.43 (Table 1 ).

Concerning answering of questionnaire more than halve of them 56.6 percent prefer clinical round in hospital than simulation-based education as method of teaching 38.8 percent (Table 2).

Regarding contribution of tutor in the teaching more than halve of answering it was more effective in simulationbased learning 51.9 percent followed by more in real patient's clinical round 41.1 percent and least of answers there was no difference between them 4.7 percent (Table 3).

Concerning clearly defined of course objective 45.7 percent of participant state that it was clearly defined in simulationbased learning while 29.5 percent state that in both and 21.7 percent stated it was clearly defined in clinical round (Table 4).

More than halve of them stated that the course objectives covered by clinical round 55 percent and 42.6 percent stated it by simulation-based learning respectively. Near halve of participant mention that the exam percentage was better covered in topic taught by clinical rounds in hospital 49.6 percent followed by 36.4 percent chooses simulation based learning while 10.9 percent state that there was no difference between both of them (Table 5 and 6).
On the other hand independent sample t- test was performed in obstetric exam for final years student to match between students mark and answering in questionnaire and to assess which is better by final mark clinical rounds in hospital or simulation based learning question, the test shows the minimum - maximum, means values for clinical round exam were 5-18 marks, means was $11.12 \pm 2.42$ while for simulation based learning exam the test shows that the minimum - maximum, values were 10 20 marks, means $17.22 \pm 2.32$. Independent sample t- test shows that there was significant difference between student mark in clinical round and simulation based learning by 99 percent confidence interval of difference, this test clarify that simulation based learning better than clinical round as method of teaching ( $p$ value less than 0.0 ), (Table 7 a \& 7b).

\section{Discussion}

This study demonstrate that simulation based learning is better than clinical round in obstetrics as concerning contribution of tutor in the teaching in more than halve of answering it was more effective in simulation based learning 51.9 percent followed by in real patients clinical round 41.1 percent. 45.7 percent of the students stated that the course objective clearly defined in simulation-based learning while 29.5 percent of them state that in both and 21.7 percent stated it was clearly defined in clinical round. More than halve of them stated that the course objectives covered by clinical round 55 percent and 42.6 percent stated it by simulation-based learning respectively. The exam results go with logic and future and matching with the previous studies and the literature and demonstrated that simulation based learning is better in obstetric examination. No similar studies comparing simulation with clinical round found in open literature on the other hand previous studies done by Dayal, et al to determine the relationship between simulation training for vaginal delivery and in a live deliveries during the clinical rotation and to assess medical students performance and confidence in vaginal delivery maneuver with and without simulation training and found that student who receive simulation training is actively in clinical environments during the course of clerkship. ${ }^{4}$ Jude DC et al determine the effectiveness of obstetric simulator training for medical student by measuring confidence in normal skill in obstetrics in with and without training and found that student whom received simulation attempt vaginal delivery independently than in receiving lecture only. ${ }^{5}$ Alfred Lee Change et al compare between simulation based training education and lecture based education in teaching situation awareness also found that simulation training and lecture training has modest significant 
difference on the total situation awareness global assessment technique and simulation training has superior effect. ${ }^{6}$ The results of our study also go online with study done by Ahmad et al. whom found significant satisfaction and self-reporting in undergraduate student toward normal labour using simulator compare to observation of real labour in labour room. ${ }^{7}$

\section{Conclusion}

Simulation based education is a better and filling the gap in teaching obstetric curriculum in under graduate medical students especially with an increasing number of medical students and scares number of patients accepting teaching on them with other logistic factors make access to real patients areal difficulty.

\section{Recommendations}

The study recommends more studies in simulation teaching should be done involving other departments and faculty staff and comparing the experience and facilities in other national universities.

\section{References}

1. McGaghie WC, Issenberg SB, Petrusa ER, et al. A critical review of simulation-based medical education research: 2003-2009 Med Educ. 2010;44:50-63.

2. https://en.wikipedia.org/wiki/Medical_simulation, medical simulation, (accessed 4-7-2017 at 2:00 AM).

3. http://www.ohsu.edu/xd/education/simulation-atohsu/about/types/ Simulation at OHSU. Types of Simulation (accessed 4-7-2017 9:17 pm)

4. Dayal AK, Fisher N, Magrane D, et al. Simulation training improves medical students' learning experiences when performing real vaginal deliveries. Simul Healthc. 2009;4(3):155-159.

5. Lee Chang $A$, Dym AA, Venegas-Borsellino $C$, et al. Comparison between simulation-based training and lecture-based education in teaching situation awareness. A randomized controlled study. Ann Am Thorac Soc. 2017;14(4):529-535.

6. Almrstani AM, Eldeek B, Sait $H$, et al. Effect of birth simulator -based teaching of vaginal delivery on undergraduate learning satisfaction. JoKULL J. 2014;64(11):165-176.

7. Jude DC, Gilbert GG, Magrane D. Simulation training in the obstetrics and gynecology clerkship. Am J Obstet Gynecol. 2006;195(5):1489-1492.

\section{ACKNOWLEDGEMENT}

Authors would like to thank all students in final year semester 11 at Faculty of medicine of Alneelain University for granted an approval and helping in data collection in this study.

\section{PEER REVIEW}

Not commissioned. Externally peer reviewed.

\section{CONFLICTS OF INTEREST}

The authors declare that they have no competing interests.

\section{FUNDING}

None

\section{ETHICS COMMITTEE APPROVAL}

The thesis approved by committee of Al Neelain University Faculty of Medicine. 
Table 1: Frequency distribution of age group

\begin{tabular}{|c|c|c|c|c|}
\hline Age group & Frequency & Percent & $\begin{array}{c}\text { Valid } \\
\text { Percent }\end{array}$ & $\begin{array}{c}\text { Cumulative } \\
\text { Percent }\end{array}$ \\
\hline $\begin{array}{c}21-25 \\
\text { years }\end{array}$ & 126 & 97.7 & 97.7 & 97.7 \\
\hline $\begin{array}{l}26-30 \\
\text { years }\end{array}$ & 1 & 0.8 & 0.8 & 98.4 \\
\hline $\begin{array}{l}31-35 \\
\text { years }\end{array}$ & 1 & 0.8 & 0.8 & 99.2 \\
\hline $\begin{array}{l}41-44 \\
\text { years }\end{array}$ & 1 & 0.8 & 0.8 & 100 \\
\hline Total & 129 & 100 & 100 & \\
\hline Minimum =21, maximum=44, mean = 23.43 years \\
\hline
\end{tabular}

Table 2: Preferred method of teaching

\begin{tabular}{|l|l|l|l|l|}
\hline $\begin{array}{l}\text { Prefer method of } \\
\text { teaching }\end{array}$ & Frequency & Percent & $\begin{array}{l}\text { Valid } \\
\text { Percent }\end{array}$ & $\begin{array}{l}\text { Cumulative } \\
\text { Percent }\end{array}$ \\
\hline $\begin{array}{l}\text { Clinical round in } \\
\text { hospital }\end{array}$ & 73 & 56.6 & 56.6 & 61.2 \\
\hline Simulation & 50 & 38.8 & 38.8 & 100 \\
\hline Both of them & 6 & 4.7 & 4.7 & 4.7 \\
\hline Total & 129 & 100 & 100 & \\
\hline
\end{tabular}

Table 3: Contribution of the tutor in the teaching

\begin{tabular}{|c|c|c|c|c|}
\hline $\begin{array}{c}\text { Contribution of } \\
\text { the tutor in the } \\
\text { teaching }\end{array}$ & Frequency & Percent & $\begin{array}{c}\text { Valid } \\
\text { Percent }\end{array}$ & $\begin{array}{c}\text { Cumulative } \\
\text { Percent }\end{array}$ \\
\hline Not mention & 3 & 2.3 & 2.3 & 2.3 \\
\hline $\begin{array}{c}\text { More effective in } \\
\text { simulation based } \\
\text { learning }\end{array}$ & 67 & 51.9 & 51.9 & 54.3 \\
\hline $\begin{array}{c}\text { More in real pt } \\
\text { clinical round }\end{array}$ & 53 & 41.1 & 41.1 & 95.3 \\
\hline No difference & 6 & 4.7 & 4.7 & 100 \\
\hline Total & 129 & 100 & 100 & \\
\hline
\end{tabular}

Table 4: Course objective clearly defined by?

\begin{tabular}{|c|c|c|c|c|}
\hline $\begin{array}{c}\text { Course objective } \\
\text { clearly defined by? }\end{array}$ & Frequency & Percent & $\begin{array}{c}\text { Valid } \\
\text { Percent }\end{array}$ & $\begin{array}{c}\text { Cumulative } \\
\text { Percent }\end{array}$ \\
\hline Not mention & 4 & 3.1 & 3.1 & 3.1 \\
\hline Both of them & 38 & 29.5 & 29.5 & 32.6 \\
\hline Clinical round & 28 & 21.7 & 21.7 & 54.3 \\
\hline $\begin{array}{c}\text { Simulation based } \\
\text { learning }\end{array}$ & 59 & 45.7 & 45.7 & 100 \\
\hline Total & 129 & 100 & 100 & \\
\hline
\end{tabular}


Table 5: Is the course objective covered by?

\begin{tabular}{|c|c|c|c|c|}
\hline $\begin{array}{c}\text { Course objective } \\
\text { covered by? }\end{array}$ & Frequency & Percent & $\begin{array}{c}\text { Valid } \\
\text { Percent }\end{array}$ & $\begin{array}{c}\text { Cumulative } \\
\text { Percent }\end{array}$ \\
\hline Not mention & 3 & 2.3 & 2.3 & 2.3 \\
\hline Clinical round & 71 & 55 & 55 & 57.4 \\
\hline $\begin{array}{c}\text { Simulation based } \\
\text { learning }\end{array}$ & 55 & 42.6 & 42.6 & 100 \\
\hline Total & 129 & 100 & 100 & \\
\hline
\end{tabular}

Table 6: Exam percentage was better in topics taught by?

\begin{tabular}{|c|c|c|c|c|}
\hline Frequency & Frequency & Percent & $\begin{array}{c}\text { Valid } \\
\text { Percent }\end{array}$ & $\begin{array}{c}\text { Cumulative } \\
\text { Percent }\end{array}$ \\
\hline Not mention & 4 & 3.1 & 3.1 & 3.1 \\
\hline Clinical rounds & 64 & 49.6 & 49.6 & 52.7 \\
\hline No difference & 14 & 10.9 & 10.9 & 63.6 \\
\hline $\begin{array}{c}\text { Simulation } \\
\text { based learning }\end{array}$ & 47 & 36.4 & 36.4 & 100 \\
\hline Total & 129 & 100 & 100 & \\
\hline
\end{tabular}

Table 7: Independent sample t- test to compare student mark in simulation versus clinical round in obstetric exam for final years student

a. Mean

\begin{tabular}{|l|l|l|l|l|l|}
\hline Type of exam & Mean & N & $\begin{array}{l}\text { Std. } \\
\text { Deviation }\end{array}$ & Minimum & Maximum \\
\hline Clinical round (patient history) & 11.1241 & 137 & 2.42973 & 5 & 18 \\
\hline Simulation (speculum ) & 17.2263 & 137 & 2.32946 & 10 & 20 \\
\hline Total & 14.1752 & 274 & 3.87137 & 5 & 20 \\
\hline
\end{tabular}

\section{b. t-test for equality of means}

\begin{tabular}{|c|c|c|c|c|c|c|c|}
\hline \multirow{2}{*}{} & \multirow{2}{*}{$\mathrm{t}$} & $\mathrm{df}$ & \multirow{2}{*}{$\begin{array}{c}\text { Sig. (2- } \\
\text { tailed) }\end{array}$} & $\begin{array}{c}\text { Mean } \\
\text { Difference }\end{array}$ & $\begin{array}{c}\text { Std. Error } \\
\text { Difference }\end{array}$ & \multicolumn{2}{|c|}{$\begin{array}{c}\text { 99\% Confidence interval of the } \\
\text { difference }\end{array}$} \\
\cline { 5 - 8 } & & & 0 & $-6.10219-$ & 0.28758 & $-6.84817-$ & $-5.35621-$ \\
\hline \multirow{2}{*}{ Marks } & $-21.219-$ & 272 & 0 & $-6.10219-$ & 0.28758 & $-6.84818-$ & $-5.35620-$ \\
\cline { 6 - 8 } & $-21.219-$ & 271.518 & 0 &
\end{tabular}

